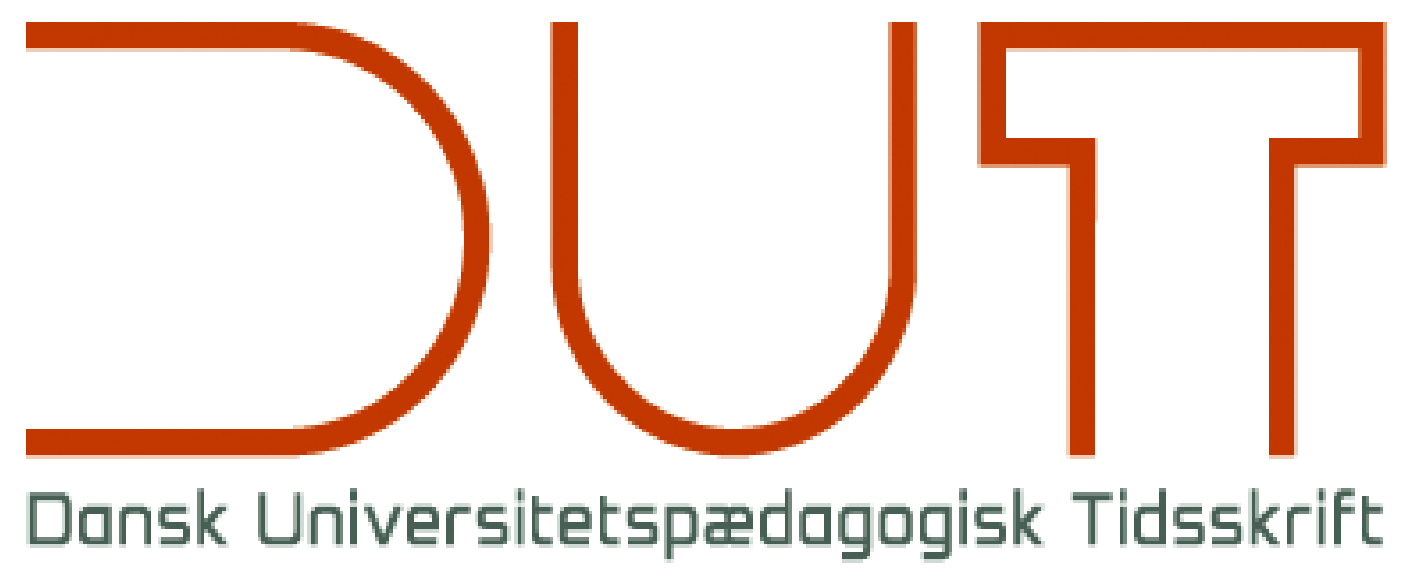

Tema

Undervisningens teknologier og teknikker

Årgang 15 nr. 28 / 2020

Titel

Usynlige konventioner: Objektsproglige størrelser i studentertekster som eksempel på hidden literacy

Forfattere

Sidetal

Alexandra Holsting, Jesper Tinggaard Svendsen, Anna Vibeke Lindø, Jesper Knudsen

86-106

Udgivet af

URL

Dansk Universitetspædagogisk Netværk, DUN

> http://dun-net.dk/

Betingelser for brug af denne artikel

(c) Copyright
Denne artikel er omfattet af ophavsretsloven, og der må citeres fra den. Følgende betingelser skal dog være opfyldt:

- Citatet skal være i overensstemmelse med "god skik"

- Der må kun citeres „i det omfang, som betinges af formålet“

- Ophavsmanden til teksten skal krediteres, og kilden skal angives ift. ovenstående bibliografiske oplysninger.

DUT og artiklens forfatter 


\title{
Usynlige konventioner: Objektsproglige størrelser i studentertekster som eksempel på hidden literacy
}

\author{
Alexandra Holsting ${ }^{a, 1}$, Jesper Tinggaard Svendsen ${ }^{b}$, Anna Vibeke Lind $\varnothing^{c}$, Jesper Knudsen ${ }^{d}$ \\ a,b,c,d, Institut for Sprog og Kommunikation, Syddansk Universitet
}

Videnskabelig artikel, fagfællebedømt

\begin{abstract}
Formålet med nærværende artikel er at undersøge, hvordan nyindskrevne dansk- og journalistikstuderende håndterer et centralt aspekt af akademisk skrivning, nemlig inddragelse af sproglige størrelser fra en empiritekst. Gennem et kvantitativt studie af 100 kortere studentertekster kortlægger vi, i hvilket omfang de studerende markerer sådanne størrelser, og hvordan de gør det. Den fagtradition, vi undersøger, sprogvidenskaben, har en klar konvention for, hvordan sådanne størrelser skal håndteres, men denne konvention er næppe kendt af dem, der ikke er en del af det faglige fællesskab. Fremgangsmåden for dette forklares sjældent eksplicit i gængs håndbogslitteratur, men manifesterer sig i stedet som tavs viden og kan dermed ses som et eksempel på hidden literacy. Vi argumenterer i artiklen for, at et skrivepædagogisk fokus på sådanne tekstlige formalia, der ikke umiddelbart synes at tjene et indholdsmæssigt formål, kan bidrage til at øge indsigten i den videnskabelige genres konstituerende elementer.
\end{abstract}

\section{Indledning}

Opgaveskrivning er en helt central aktivitet på universitetet, idet mestring af akademisk skrivning som formidling af faglig kunnen åbner muligheden for at indgå i det faglige fortolkningsfællesskab (Swales, 1990) og således er en afgørende faktor for at klare sig godt (Verheijen, 2015). Det kan imidlertid være vanskeligt for den studerende at håndtere akademisk sprog sammenlignet med andre registre (Snow \& Uccelli, 2009), ikke mindst pga. de mange implicitte krav til den akademiske opgave. Et særligt konstituerende træk ved den akademiske opgave er, at den studerende skal mestre at inddrage to typer af kilder, hhv. den relevante forskningslitteratur og den empiri, der undersøges. Gennem de senere år har der i forskningen i akademisk skrivning været et stigende fokus på, hvordan universitetsstuderende inddrager forskningslitteratur i deres opgaver, og i den forbindelse på de udfordringer, der er forbundet hermed (se Verheijen, 2015, for en oversigt). I forlængelse heraf har plagiatrelaterede problemer fået stor opmærksomhed (Pecorari \& Petric, 2014). Også inden for håndbogslitteraturen rettet mod akademisk skrivning er inddragelsen af forskningslitteratur, herunder regler for citationspraksis, velbeskrevet (fx Swales \& Feak, 2012; Osmond, 2016; Toft, 2016; Wegener, 2016; Rienecker \& Jørgensen, 2017). Os bekendt er det imidlertid hverken i dansk eller international kontekst undersøgt, hvordan universitetsstuderende inddrager empiritekster i deres opgaver, og dette aspekt omtales ligeledes ikke eksplicit i håndbogslitteraturen, når andre aspekter af akademisk skrivning eksemplificeres. Således viser fx Rienecker \& Jørgensen (2005, s. 184) et eksempel på en analyse, hvor der indgår uddrag fra en empiritekst, men hverken her eller andre steder i bogen præciseres det, hvordan - og hvorfor inddragelse af empiritekst markeres.

${ }^{1}$ Kontakt: aho@sdu.dk 
For at blive klogere på denne underbelyste del af akademisk skrivning vil vi i denne artikel undersøge, i hvilket omfang og hvordan nyindskrevne studerende på dansk- og journalistikstudierne på SDU markerer, at sproglige størrelser i deres tekst stammer fra en empiritekst. Vores datasæt består af 100 kortere opgaver, der med udgangspunkt i en avisartikel beskriver pronominers rolle i etablering af tekstsammenhæng (kohæsion). I disse opgaver får empiriteksten en særlig status, da de studerendes fokus i mindre grad er rettet mod tekstens indhold og i højere grad mod nogle almene sproglige mekanismer, der kan iagttages udfoldet i empiriteksten. De størrelser fra empiriteksten, der optræder i de studerendes opgaver, får dermed status af objektsprog (jf. fx Hjelmslev 1973, s. 128f.), der inden for det sprogvidenskabelige fagfællesskab kræver en særlig form for markering (se afsnit 3).

Artiklens teoretiske udgangspunkt er Academic Literacies-perspektivet (Ivanic, 1998; Lea \& Street, 1998; Barton, Hamilton \& Ivanic, 2000). Det indebærer bl.a., at vi anskuer akademisk skrivning som en socialt situeret praksis, hvor tidligere og aktuelle genrenormer mødes og også brydes. For den studerende indebærer dette, at hun skal tilpasse sig en række genrenormer, der ofte kun eksisterer som tavs viden, og håndtering af objektsprog er netop et eksempel på en i høj grad implicit og meget fagspecifik genrenorm. Umiddelbart er der tale om et fænomen, der kan betragtes under overskriften formalia, men det er en pointe for artiklen, at de formelle ressourcer tjener en central rolle i forhold til at markere funktionelle niveauer $\mathrm{i}$ teksten og i sidste ende gøre denne forståelig for læseren. Vores fokus i undersøgelsen er derfor ikke kun at afdække graden af beherskelse af denne norm, men i lige så høj grad at afdække, om teksterne vidner om en forståelse af, at formalia har en kommunikativ funktion.

I det følgende vil vi i afsnit 2 gøre rede for vores teoretiske udgangspunkt og i afsnit 3 for fænomenet objektsprog, der omfatter eksempler og objektsproglige størrelser i løbende tekst, samt de konventioner, der er knyttet til markering af sådanne. I afsnit 4 beskriver vi den undersøgelse, der ligger til grund for artiklen, og i afsnit 5 vores analyser og resultater. I afsnit 6 diskuterer vi undersøgelsens resultater og peger på mulige perspektiver $\mathrm{i}$ forhold til undervisning i akademisk skrivning, og i konklusionen (afsnit 7) sammenfatter vi artiklens fund.

\section{Teoretisk udgangspunkt}

Vores teoretiske udgangspunkt er Academic Literacies, som er betegnelsen for et skrivepædagogisk felt, der blev udviklet i 1990'erne (Lea \& Street, 1998). Denne tilgang betragter skrivning og læring som nært forbundne og anlægger med sit afsæt i sociologisk funderet sprogteori et syn på skriftlighed som en kontekstsensitiv, social og kulturel proces. Med denne tilgang kan opgaveskrivning ikke reduceres til at angå en række isolerede kognitive færdigheder, som den enkelte studerende blot kan optræne uafhængigt af uddannelsesmæssig baggrund og uafhængigt af de (nye) kontekster, hvor opgaveskrivningen finder sted (Lea \& Street, 1998; Robinson-Pant \& Street, 2012). Academic Literacies betoner derimod, at akademisk skrivning implicerer et ideologisk plan, hvor selve reglerne for konstruktion af faglig viden og spørgsmålet om, hvilke(n) identitet(er) der har adgang til akademisk skrivning, skal adresseres (Lea, 2012; Robinson-Pant \& Street, 2012). Hermed bliver akademisk skrivning et spørgsmål om magt - og ikke mindst afmagt -, da de diskursive praksisser, regler og normer, der understøtter den af fortolkningsfællesskabet anerkendte akademiske opgave, ofte er implicitte. Af denne grund har det inden for Academic Literacies særlig bevågenhed at belyse de skjulte literacies, som den akademiske opgaveskrivning forudsætter, og som den ligeledes vurderes ud fra (Lillis, 2004; Street, 2009). 
Den akademiske opgave anskues med dette afsæt ikke ud fra en rigtig-forkert-optik, men kan i stedet betragtes som et møde mellem tidligere og aktuelle normer for opgaveskrivning (Lea, 2004, s. 744). Academic Literacies-perspektivet tager her afsæt i Bakhtins (1981) forståelse af sproget som dialogisk, hvilket manifesterer sig i, at en tekst ses som konstitueret af et sammenrend af 'stemmer' og dermed som en intertekstuel størrelse (Scott \& Turner, 2009). Det, der ud fra nogle traditioner ville blive betragtet som 'fejl', kan med Burgess (2004, s. 43) forstås som sammenstød (cruses) mellem kontekster. En undersøgelse af disse sammenstød kan således bidrage til at belyse, om der i konkrete tilfælde er tale om en generel afstand mellem den akademiske institutions (implicitte) forventninger og de studerendes skrivehandlinger - og dermed om der er tale om hidden literacies.

Academic Literacies-perspektivet indebærer ofte et fokus på skriftlighedens makrostrukturer. Vi argumenterer imidlertid med Hyland (2013) for, at også tekstens umiddelbart mere formelle træk har en retorisk funktion, og at vi også her finder eksempler på både generiske og fagspecifikke literacies. Disse kan ses som bærere af større kulturelle og samfundsmæssige værdier, der ikke bør negligeres inden for skriveforskningen.

I vores undersøgelse har vi fokus på et sådant fagspecifikt formelt træk, nemlig markeringen af empiritekst i sprogvidenskabelige tekster. Denne markering har en intertekstuel funktion i forhold til at organisere tekstens forskellige niveauer, og den er stærkt konventionaliseret inden for det faglige fællesskab (se afsnit 3), men ses sjældent ekspliciteret uden for dette (se afsnit 1). Den udgør dermed et eksempel på en hidden literacy.

\section{Objektsprog som analysekategori}

Inddragelse af empiritekster tjener en funktion i forhold til at illustrere og eksemplificere i en analyse. I en sprogvidenskabelig sammenhæng vil det ofte betyde, at betydningen træder i baggrunden, mens formen bliver det centrale. Dette udspringer af, at sprog for sprogvidenskaben både udgør mediet og genstanden, hvilket i teksten gør det nødvendigt at etablere en skelnen mellem de sproglige fænomener, der fungerer som genstand (objektsprog), og de, der fungerer som beskrivelse (metasprog). Når sproglige størrelser tilskrives en status som objektsprog, bruges de ikke længere med reference til en verden uden for sproget (language use), men derimod i deres egenskab af sprog (language mention). De forskellige funktioner kan illustreres af substantivet skov i eksemplerne (1) og (2):

(1) Der ligger en stor skov i Nordjylland.

(2) Skov er et substantiv.

I (1) refererer skov til en type fænomen uden for sproget, i (2) refererer skov til sig selv som ord. Forskellen ses både ved indholdsord, dvs. substantiver, verber, adjektiver og adverbier, og ved grammatiske funktionsord, fx præpositioner, konjunktioner og pronominer.

Vi skelner i det følgende mellem to måder, hvorpå objektsprog optræder i en tekst. Den ene er som eksempel, der er tydeligt afgrænset fra den omgivende tekst, den anden er som en størrelse i den løbende tekst. I eksempel (3) nedenfor gengives en forudgående passage fra nærværende artikel, og vi har her indrammet de størrelser, der fungerer som hhv. eksempler (firkant) og objektsproglige størrelser i den løbende tekst (cirkler): 
(3)

(1)

(2)

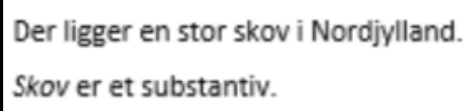

I (1) refererer(skov)til en type fænomen uden for sproget, i (2) refererer skovtil sig selv som ord. Forskellen ses báde ved indholdsord (substantiver, verber, adjektiver og adverbier), og ved grammatiske funktionsord, fx præpositioner, konjunktioner og pronominer.

For at sikre, at læseren kan adskille de objektsproglige størrelser fra den omgivende tekst, har vi - i overensstemmelse med konventionen - markeret disse visuelt på forskellig vis. Eksemplerne er afgrænset ved hjælp af tekstens layout: De står på linjer for sig selv, de er indrykket i forhold til venstre margen, og de er nummereret. De objektsproglige størrelser i den løbende tekst skiller sig typografisk ud fra omgivelserne ved at stå i kursiv. Uden brug af disse ressourcer ville vi få en tekst i stil med den følgende:

(4) Der ligger en stor skov i Nordjylland. Skov er et substantiv. Først refererer skov til en type fænomen uden for sproget, dernæst refererer skov til sig selv som ord. Forskellen ses både ved indholdsord, dvs. substantiver, verber, adjektiver og adverbier, og ved grammatiske funktionsord, fx præpositioner, konjunktioner og pronominer.

Teksten i (4) er væsentligt sværere at læse end teksten i (3), hvilket begrunder konventionen om, at eksempler og objektsproglige størrelser i løbende tekst markeres, så de skiller sig ud fra den omgivende tekst. Her udgør førnævnte brug af layout og typografi standarden i sprogvidenskabelige tekster (se fx Esser 2006, s. 98; Haspelmath, 2014; Lehmann, 2013;).

Før computerens udbredelse var kursiv kun en mulighed i udgivelses- og trykkeprocessen, og almindelige manuskripter, udfærdiget på skrivemaskine, anvendte i stedet understregning (jf. Hagiwara, 2005, s. 4) eller tegnsætning i form af enkelte eller dobbelte citationstegn (Bußmann, 1990, s. 540). Nu om stunder, hvor manuskripter som standard udarbejdes på computer, har kursiven etableret sig som standard, mens understregning og dobbelte og enkelte citationstegn har fået andre specialiserede funktioner som henholdsvis emfase, egentligt citat og angivelse af betydning. ${ }^{2}$

Brugen af kursiv og layout ovenfor er udtryk for en konvention i den forstand, at adskillelsen af de to lag (det objektsproglige og det ikke-objektsproglige) skal etableres på en eller anden måde, for at teksten er forståelig, men ret beset gør det ingen forskel, om vi vælger den ene eller den anden måde. Der ligger således ingen særlig betydning i fx kursivbrugen dens funktion etableres alene ved, at den er en modsætning til ikke-kursiv. ${ }^{3}$

Fælles for layout og kursiv er, at de markerer de objektsproglige størrelser, så de står visuelt ud i forhold til den omgivende tekst. Sådanne markeringer kan understøttes af en sproglig

\footnotetext{
${ }^{2}$ Umiddelbart kan citatet og objektsproget synes at have et overlap, når der er tale om elementer fra en empiritekst. Som påpeget af Wilson $(2018$, s. 82) adskiller de sig ved, at objektsproget figurerer som form, mens citatet figurerer som form og betydning.

${ }^{3}$ Således kan kursiv/ikke-kursiv-mønstret også vendes, hvis en objektsproglig størrelse fx figurerer i en sammenhæng, hvor ikke-objektsprog af en eller anden grund skal i kursiv, fx en bogtitel. Her vil den objektsproglige størrelse adskille sig fra den omgivende tekst ved ikke at stå i kursiv.
} 
klassificering af størrelserne som objektsproglige. Det kan illustreres med følgende eksempler fra vort datamateriale: ${ }^{4}$

(5) Prominent ham refererer tilbage til en person, men hvem? (tekst 43)

(6) Proformen ham skal i den her sætning føre tilbage til det betydningsbærende morfem Jørgen Lund. (tekst 2)

(7) Her refererer proformet "den" til ordet "cykel" i den tidligere sætning. (tekst 15)

I (5) er den objektsproglige størrelse ham ikke markeret. Gennem de sproglige omgivelser klassificeres ham imidlertid som et pronomen (prominent = pronomenet), hvilket trods alt understøtter læsningen og gør det muligt at identificere ham som en objektsproglig størrelse. I (6) er den ene objektsproglige størrelse (ham) markeret med kursiv, mens den anden (ઇørgen Lund) ikke er; begge er klassificeret som objektsprog gennem de sproglige omgivelser. I (7) er begge objektsproglige størrelser markeret med dobbelt citationstegn, og den objektsproglige status understøttes af de sproglige omgivelser (proformet (=proformen) og ordet). Selvom de sproglige omgivelser kan lette læsningen, tilsiger konventionen, at en objektsproglig størrelse skal markeres visuelt, og ud fra dette perspektiv er ham i (5) og Jørgen Lund i (6) utilstrækkeligt markeret. Vi er dermed inde på et felt, hvor tekstens betydninger (her adskillelsen af egen og andres tekst) realiseres multimodalt (jf. fx Kress, 2003; Kress \& van Leeuwen, 2001; Machin, 2007).

Ud over konventionen om det, vi kan kalde visuel markering, er også en anden konvention relevant, nemlig den, der angår konsekvens. Selvom det sjældent ses ekspliciteret, forventer vi, at en teksts afsender holder sig til én form i de tilfælde, hvor der findes flere muligheder. Det gælder $\mathrm{fx}$ inden for retskrivningen, når flere stavemåder er mulige (fx ressource og resurse), i dansk tegnsætning, hvor man kan vælge at sætte startkomma eller lade være, og også mere overordnet i forhold til sproglig kode, hvor man fx kan udtrykke sig på britisk eller amerikansk engelsk. I alle tilfælde har vi en forventning om, at afsenderen holder sig til én form inden for samme tekst. Dette gælder også i tilfældet med markering af eksempler og objektsproglige størrelser.

Samlet set er der dermed tale om en konvention for markering af empiritekst, der kan deles $\mathrm{i}$ tre. For det første kræver konventionen, at eksempler og objektsproglige størrelser i løbende tekst markeres visuelt, så det er tydeligt, at de har en anden status end den omgivende tekst. En medfølgende sproglig klassificering kan understøtte dette, men anses ikke i sig selv for tilstrækkelig. For det andet er den typisk anvendte visuelle markering i det akademiske fællesskab, at eksempler markeres ved hjælp af layout (linjeskift, nummerering), mens objektsproglige størrelser i løbende tekst markeres ved hjælp af typografi (og her er kursiv absolut mest udbredt) eller i sjældnere tilfælde tegnsætning (citationstegn). Endelig er der en forventning om, at de valgte ressourcer bruges konsekvent. I vores undersøgelse, der beskrives i afsnit 5, er vi interesseret i alle tre aspekter af konventionen.

\footnotetext{
${ }^{4}$ I alle eksempler fra korpus er originaltekstens stavning og tegnsætning bibeholdt. I de tilfælde, hvor vores analyse vedrører tekstens layout, har vi desuden gengivet originaltekstens layout (se fx (9)).
} 


\section{Undersøgelsesdesign}

Vores undersøgelser af nyindskrevne studerendes håndtering af objektsprog i deres akademiske opgaver består af analyser af 100 mindre skriftlige opgaver udarbejdet af studerende på danskstudiet og journalistikstudiet på SDU i september 2015..$^{5}$ Opgavernes omfang er i gennemsnit på 445 ord, med 800 ord som det højeste og 192 ord som det laveste. Medianen er 431 ord.

Der er tale om en skriftlig stedprøve, der fungerer som en såkaldt studiestartsprøve, hvilket indebærer, at deltagelse i prøven er en forudsætning for at kunne fortsætte på studiet. Der stilles dog ikke krav om et specifikt fagligt niveau for opgaven, hvilket de studerende er informeret om, når de udarbejder denne. ${ }^{6}$

De studerende har haft 60 min til at udarbejde opgaven, der består af tre dele:

1. En redegørelse for de væsentligste begreber i en teoritekst. Teksten er et uddrag af en indførende lærebog i tekstlingvistik (Holm, 2007), der behandler pronominers funktion som kohæsionsskabende ressourcer. Teoritekstens omfang er på 4 sider (ca. 1100 ord).

2. En analyse af en manipuleret avisartikel med henblik på pronominernes kohæsionsskabende funktion. Artiklen behandler diskussionen af en kommareform, og den er karakteriseret ved en i nogle tilfælde uhensigtsmæssig brug af pronominer. Artiklen har et omfang på 1 side (ca. 300 ord).

\section{En vurdering af avisartiklens pronomenbrug.}

Vi er bevidste om, at omstændighederne for udarbejdelsen af teksterne, der udgør vores datagrundlag, kan have påvirket disses udformning, og at de ikke nødvendigvis afspejler de studerendes reelle akademiske skriftsproglige kompetencer. Her spiller den korte tid til udarbejdelsen og det lave risikoniveau (at opgaven ikke kan dumpes) muligvis en rolle.

Eftersom analysegenstanden er sproglige størrelsers funktion i en tekst, kan det forventes, at de studerende inddrager empiriteksten i form af eksempler og objektsproglige størrelser i løbende tekst i et vist omfang. De studerende kan finde inspiration til, hvordan dette gøres, i teoriteksten, der er tydelig i sin markering af eksempler og objektsproglige størrelser i løbende tekst (se illustration 1). Her er eksempler afgrænset i forhold til den omgivende tekst, idet de optræder i farvede (blå) bokse, hvis venstre margen er indrykket i forhold til resten af teksten, og som bærer overskriften EKSEMPEL efterfulgt af kolon. Bortset fra betegnelsen EKSEMPEL indeholder disse bokse kun objektsprog. Der er anvendt samme typografi i boksene som

\footnotetext{
${ }^{5}$ I alt blev der ved denne prøve udarbejdet 160 opgaver. For at kompensere for skæv kønsfordeling lavede vi en undersampling med i alt 100 opgaver, hvoraf 50 opgaver er lavet af journaliststuderende og 50 udarbejdet af danskstuderende (se evt. Blom et al., 2017 og Holsting et al. 2017 for en nøjere beskrivelse).

${ }^{6} \mathrm{Vi}$ vil gerne takke lektor, ph.d. Jonas Blom og lektor, ph.d. Kenneth Reinicke for at have udarbejdet undersøgelsens design. Vi takker ligeledes de dansk- og journaliststuderende, der deltog i undersøgelsen, og som tillod os at bruge deres opgaver i vores forskningsprojekt.
} 
i den omgivende tekst, og objektsproget er holdt i ikke-kursiv, bortset fra de elementer, læseren skal lægge mærke til (fx pronominer). ${ }^{7}$

Objektsproglige størrelser i den løbende tekst er markeret med kursiv, og i brødteksten er dette kursivens eneste funktion.

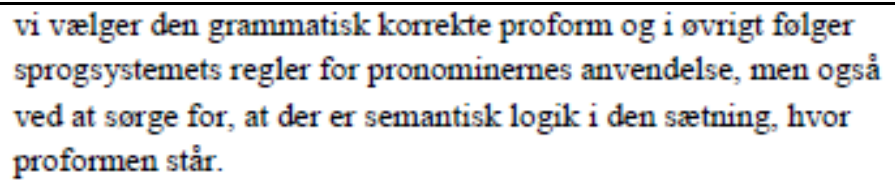

\section{EKSEMPEL:}

Katten nærmede sig musen. Den var anspæendt.

Eftersom både katten og musen kan være anspændte, kan vi ikke ud fra betydningen i sætning 2 vide, om den refererer tilbage til katten eller musen. Vi er derfor nodt til at gentage ordet

Illustration 1. Uddrag fra teoriteksten (Holm, 2007, s. 3)

\section{Analyse}

I vores analyse har vi identificeret de sproglige størrelser, der må betragtes som eksempler eller objektsproglige størrelser i løbende tekst. Da en del af undersøgelsen adresserer, hvorvidt disse størrelser overhovedet markeres, beror identifikationen naturligvis ikke på den visuelle markering, men på, hvordan ord, ordgrupper og sætninger fungerer i tekstsammenhængen, fx ham i eks. 5 ovenfor. Analysens formål var fra start at afdække, i hvilket omfang og hvordan de studerende markerede eksempler og objektsproglige størrelser i løbende tekst, hvilket beskrives i hhv. afsnit 5.1. og 5.2. For de objektsproglige størrelsers vedkommende afdækkede analysen imidlertid, at markeringshyppigheden i nogen grad afhang af den pågældende størrelses form, dvs. om der var tale om en sætning, en ordgruppe eller et ord og for ordenes vedkommende, hvilken ordklasse disse tilhørte. Vi har derfor inddraget formen som en parameter i afsnit 5.2.1 og 5.2.2., til trods for at konventionen ikke opererer med en differentiering i forhold til form.

Identifikationen af de relevante størrelser blev i visse tilfælde besværliggjort af to forhold.

For det første er der tilfælde, hvor det ikke er entydigt, om en sproglig størrelse henviser til sig selv som sprog eller til en størrelse uden for sproget. Det gælder fx ordet komma i (8):

(8) Komma nævnes ikke i sætningen, men ved hjælp af en kohæsionsforbindelse i sctte det, så ved læseren, at der er tale om kommaer. (tekst 6)

Her er det ikke muligt at afgøre, om der sigtes til ordet eller fænomenet. I sådanne tilfælde har vi ikke betragtet den sproglige størrelse som objektsproglig, medmindre den studerende har markeret den som sådan.

\footnotetext{
${ }^{7}$ Som eksempler anskuer vi sproglige størrelser, der ikke indgår i løbende tekst. Eksempler kan stamme fra empiritekst(er), men kan også være selvkonstruerede med det formål at illustrere et bestemt fænomen. I teoriteksten kan de studerende se eksempler på begge dele; af tekstens 11 eksempler er et enkelt udstyret med en kildeangivelse, hvoraf det kan sluttes, at de resterende 10 er konstruerede.
} 
For det andet er det ikke altid muligt at skelne mellem eksempler og objektsproglige størrelser i løbende tekst. Vi har baseret vores adskillelse på to forhold; for det første om der foreligger en layoutmæssig adskillelse, for det andet om den pågældende størrelse er syntaktisk integreret i den omgivende tekst. For at et element skal tælle som objektsproglig størrelse i løbende tekst, har vi krævet, at det er layoutmæssigt og syntaktisk integreret i den omgivende tekst; i alle andre tilfælde betragter vi det pågældende element som et eksempel. Af denne grund betragtes Helikopteren indhentede fuglen... i (9) og Dansk sprogncevn vil nu undersøge, hvordan vi scetter det i (10) som eksempler, mens Han er altså enig med ham... i (11) betragtes som objektsproglig størrelse i løbende tekst:

(9)

Nedenunder er illustrerer en sætning med lav kohæsion, da stedordet kan referere til begge substantiver:

"Helikopteren indhentede fuglen. Den satte farten op"

Satte fuglen farten op for at slippe væk, eller satte helikopteren farten op for at fange fuglen? På grund af den specialviden de fleste personer besidder ville vi konkludere at fuglen satte farten op for at slippe væk, da helikoptere ikke normalt anvendes til fuglejagt, men det er ikke sikkert. Den semantiske logik er ikke tydelig, dvs. at betydningen kan være svær at tolke.

(tekst 17)

(10)

Mange sætninger forstås ved læserens baggrundsviden, eller logiske sans. Mange sætninger $\mathrm{i}$ artiklen overlader det til os at vide hvad pronominerne henviser til, og man er tit nødt til at læse sætningen igen. Dansk sprognævn vil nu undersøge, hvordan vi sætter det. Kun fordi de i rubrikken har nævnt at der er tale om kommaer, har vi en chance for at vide hvad der snakkes om.

(tekst 29)

Et eksempel fra teksten kan være i linje 46, hvor der står: Han er altså enig med ham $i$, at kommaet skaber problemer. Proformen ham skal i den her sætning føre tilbage til det betydningsbærende morfem Jørgen Lund. Sætningen hvor Jørgen Lund tidligere er nævnt er i linje 36. Det er 10 linjer før, hvilket er for langt et stykke. Reference fungerer derfor ikke i praksis i dette tilfælde. Referencen er i grunden skrevet ind i teksten som en anaforisk

(tekst 2)

Af de 100 tekster indeholder de 44 et eller flere eksempler. Samlet set indeholder vores korpus 108 eksempelforekomster. Da teksterne har varierende længde, forholder vi antallet dels til konkrete enkelttekster, dels til antallet pr. 1000 ord.

\begin{tabular}{|l|l|l|}
\hline & Absolut antal & pr. 1000 ord \\
\hline laveste antal i én tekst & 1 & 1,7 \\
\hline højeste antal i en tekst & 9 & 17,3 \\
\hline median & 2 & 4,9 \\
\hline gennemsnit & 2,5 & 5,8 \\
\hline
\end{tabular}


Tabel 1. Eksempler i korpus

Af vores 100 tekster indeholder de 97 forekomster af objektsproglige størrelser i løbende tekst. Samlet set indeholder vores korpus 1494 forekomster. ${ }^{8}$

\begin{tabular}{|l|l|l|}
\hline & Absolut antal & pr. 1000 ord \\
\hline laveste antal i én tekst & 3 & 7 \\
\hline højeste antal i en tekst & 35 & 65 \\
\hline median & 14,5 & 34 \\
\hline gennemsnit & 14,9 & 33,4 \\
\hline
\end{tabular}

Tabel 2. Objektsproglige størrelser i løbende tekst i korpus

I det følgende vil vi i første omgang præsentere vores resultater for eksempler og dernæst for objektsproglige størrelser i løbende tekst. I begge tilfælde undersøger vi, i hvor høj grad der finder en markering sted, og efterfølgende hvordan der markeres.

\section{1. Eksempler}

Som eksempler har vi betragtet objektsproglige størrelser, der enten er layoutmæssigt afgrænset fra den omgivende tekst, fx (9), eller står syntaktisk uafhængigt uden at være layoutmæssigt afgrænset, fx (10). Som markering af eksempel har vi anset layoutmæssig afgrænsning eller typografisk afgræsning (fx kursivering eller citationstegn). De to ses også i kombination, fx i (9). Objektsproglige størrelser, der gives status af eksempler, har ofte sætningsform, og i vores korpus har alle eksempler form af en eller flere sætninger.

Af de 108 forekomster er de 102 markeret, svarende til 94,4 \%. De ikke-markerede forekomster er fordelt på tre tekster, hvoraf to tekster kun indeholder et eksempel (der altså ikke er markeret), mens den tredje indeholder fem eksempler, hvoraf kun et er markeret.

\begin{tabular}{|l|l|}
\hline & Antal tekster (andel) \\
\hline Alle forekomster markeret & $41(93 \%)$ \\
\hline Ikke alle/ingen forekomster markeret & $3(7 \%)$ \\
\hline
\end{tabular}

Tabel 3. Markering af eksempler

For de seks ikke-markerede forekomster gælder det, at de fem får tilskrevet en objektsproglig status ved hjælp af de sproglige omgivelser (fx Trøjen lå på gulvet, den var hullet i (12)); i det sidste tilfælde (13) er det kun et nøje kendskab til konteksten, der muliggør det for læseren at fastlægge Det skal de undersøge som eksempel:

\footnotetext{
${ }^{8}$ Vi har i optællingerne taget højde for, at der er tale om objektsproglige størrelser, ikke om objektsproglige ord. En objektsproglig størrelse kan således godt bestå af flere ord.
} 
Proformer, altså pronominerne, er de ord man sætter i stedet for et andet ord i teksten. Eks. Trøjen lå på gulvet, den var hullet. Så bliver ordet den til et pronomen, da den henviser til trøjen.

Det er vigtigt at huske at proformets fortolkning altid er afhængig af det indhold, der er i den sætning, den anvendes i.

(tekst 154)

(13)

Det skal de undersøge? Hvem er de og hvad er det de skal undersøge? Det er en meget upræcis overskrift, som intet fortæller om hvad artiklen handler om. Som læser får vi dog af vide at der er noget som skal undersøges, men vi făr ikke af vide hvad der skal undersøges og vi fằr ikke af vide hvem der skal undersøge dette.

(tekst 143)

\subsubsection{Markeringens form}

Som eksemplerne ovenfor illustrerer, benyttes der i besvarelsen en række forskellige ressourcer, som fremgår af tabel 4:

\begin{tabular}{|l|l|l|}
\hline & Antal forekomster & Fordelt på antal tekster \\
\hline Dobbelt citationstegn & 22 & 16 \\
\hline Layout & 20 & 12 \\
\hline Layout + dobbelt citationstegn & 22 & 9 \\
\hline Kursiv & 10 & 5 \\
\hline Kursiv + dobbelt citationstegn & 6 & 4 \\
\hline $\begin{array}{l}\text { Layout + dobbelt citationstegn } \\
\text { kursiv }\end{array}$ & 6 & 4 \\
\hline Layout + kursiv & 11 & 3 \\
\hline Layout + enkelt citationstegn & 2 & 2 \\
\hline Layout + nummerering & 3 & 1 \\
\hline i alt & 102 & $56^{9}$ \\
\hline
\end{tabular}

Tabel 4. Markeringsformer for eksempler

Layout, som vi forventer at se som den primære ressource, er anvendt i 64 (62,7 \%) af forekomsterne fordelt på 31 tekster. Layout og nummerering, som strengt taget er den ideelle

\footnotetext{
${ }^{9}$ Når tallet her er højere end de 44 (som er antallet af tekster, der indeholder eksempler), skyldes det, at der i nogle tekster anvendes forskellige ressourcer.
} 
form, ses kun ved tre forekomster i én tekst (som også indeholder flere forekomster, der er markeret på anden vis).

I en korrekthedsoptik vil vi forvente, at de studerende konsekvent benytter den samme form. Dette er dog ikke tilfældet. Af de 44 tekster med eksempler forekommer der i de 29 mere end ét eksempel. Blandt disse bruger de 18 konsekvent samme markering af eksemplerne, mens de 11 bruger forskellige markeringer. Det ses fx i (14), hvor det første eksempel står i dobbelte citationstegn og det andet i kursiv.

(14) Der bliver brugt et eksempel. "Butikken sælger ikke længere porcelænsfigurer. Det gjorde den tidligere(..)". Her henviser 'den' til ordet 'butikken', som blev brugt i sætningen før. Der bliver skabt en sammenhæng. [...] Når man anvender pronominer i en sætning, står den i stedet for et andet ord, som enten kom i sætningen før eller efter ordet. Emma spiste aftensmad. Hun synes, det smagte godt. Hun fører tilbage til Emma. (tekst 20)

Trods det at fravalget af layout som markeringsform indebærer, at teksten i nogle sammenhænge bliver svær at læse, så udviser de studerende stor sikkerhed i forhold til at markere det, der skal fungere som eksempler i deres tekster. Dette er måske ikke så overraskende, da det at eksemplificere er en fremstillingsform, der må formodes at blive anvendt i flere forskellige fag i både grundskole og videregående uddannelser. Der har således været flere muligheder for at få belyst konventionerne for at eksemplificere på korrekt vis gennem det tidligere uddannelsesforløb.

\section{2. Objektsproglige størrelser i løbende tekst}

Til denne kategori henregner vi objektsproglige størrelser, der ikke er afgrænset layoutmæssigt, og som kan ses som syntaktisk integreret i den omgivende tekst (fx undersøgelserne og de i (15), hans kollega i (16) og Men det er formentlig mere et udsalg af selvtillid i (17)):

(15) I stedet for "undersøgelserne" bliver der brugt "de". (tekst 116)

(16) For det første skriver forfatteren "hans kollega," som om det er en andens kollega Jørn Lund kigger på. (tekst 8)

(17) Det tages endda med videre til næste sætning, hvor der skrives: Men det er formentlig mere et udsalg af selvtillid (...). (tekst 11)

Som eksemplerne viser, kan disse størrelser formmæssigt være enkeltord, ordgrupper eller sætninger. Som markering af disse anvendes i vores korpus enkelte og dobbelte citationstegn, kursiv og understregning samt kombinationer.

Af vores korpus' 1494 forekomster af objektsproglige størrelser i løbende tekst er 1093 markeret på en af ovennævnte måder, svarende til 73,2 \%. Alle tekster, der indeholder objektsproglige størrelser i løbende tekst, markerer minimum én af disse. Tabel 5 viser, hvor stor en andel af de objektsproglige størrelser de enkelte tekster markerer. 


\begin{tabular}{|l|l|l|}
\hline $\begin{array}{l}\text { Markering af objektsprog- } \\
\text { lige størrelser i løbende } \\
\text { tekst }\end{array}$ & Antal opgaver & Andel \\
\hline $100 \%$ & 12 & $12 \%$ \\
\hline $90-99 \%$ & 14 & $14 \%$ \\
\hline $80-89 \%$ & 22 & $23 \%$ \\
\hline $70-79 \%$ & 15 & $15 \%$ \\
\hline $60-69 \%$ & 16 & $16 \%$ \\
\hline $50-59 \%$ & 8 & $8 \%$ \\
\hline $40-49 \%$ & 5 & $5 \%$ \\
\hline $30-39 \%$ & 1 & $1 \%$ \\
\hline $20-29 \%$ & 2 & $2 \%$ \\
\hline $10-19 \%$ & 0 & 0 \\
\hline $1-9 \%$ & 2 & $2 \%$ \\
\hline $0 \%$ & 0 & 0 \\
\hline & 97 & \\
\hline
\end{tabular}

Tabel 5. Markering af objektsproglige størrelser i løbende tekst

Som udgangspunkt angiver dette, at $12 \%$ af de deltagende studerende behersker dette aspekt af akademisk skrivning, mens de resterende $88 \%$ ikke markerer konsekvent og dermed demonstrerer forskellige grader af usikkerhed. En mere positiv udlægning er dog, at langt de fleste - $90 \%$ - formår at markere halvdelen eller flere af de objektsproglige størrelser i deres tekster, og at alle som nævnt markerer minimum én. Dette ser vi som en indikation på, at de pågældende studerende i et eller andet omfang har en bevidsthed om nødvendigheden af at adskille objektsprog fra den omgivende tekst, og at 'systemet' dermed ikke er dem helt fremmed. ${ }^{10}$ Hvorvidt dette hviler på, at de studerende tidligere har indgået i undervisningsmæssige sammenhænge, hvor en skelnen mellem objektsprog og ikke-objektsprog er blevet tematiseret, eller om det skyldes en mere intuitiv forståelse af behovet for at adskille disse niveauer, kan vi ikke afgøre på baggrund af teksterne.

\subsubsection{Typer af objektsproglige størrelser}

Når vi ser nærmere på de tekster, der ikke markerer alle forekomster, kan vi umiddelbart iagttage, at karakteren af den objektsproglige størrelse i et vist omfang er udslagsgivende for, hvor hyppigt denne markeres eller ikke markeres. Vi har derfor inddelt forekomsterne i fem eksklusive grupper, der er defineret ud fra formen:

${ }^{10}$ Selv i det tilfælde, hvor kun en enkelt objektsproglig størrelse er markeret, forekommer det mere sandsynligt, at denne markering er bevidst, og at de ikke-markerede forekomster er udtryk for forglemmelser, end at markeringen af den ene forekomst er sket ved en fejl. 
- Sætninger: Her medtager vi hele sætninger (helsætninger, hovedsætninger, ledsætninger), men også sætningsfragmenter og konstruktioner med flere sætninger.

- Pronominer: Denne gruppe indeholder alle pronomenformer, om end det er personlige pronominer, der er langt mest forekommende.

- Substantiver i form af appellativer

- Substantiver i form af proprier

- Andet: Denne kategori dækker alle forekomster, der ikke passer ind i ovenstående, fx verber, adverbier og ordgrupper.

Tabel 6 illustrerer antallet af forekomster af den pågældende type, samt antallet af tekster, i hvilke den pågældende type forekommer:

\begin{tabular}{|l|l|l|}
\hline & Antal forekomster i korpus & Antal tekster med forekomst \\
\hline pronomen & $820(54,9 \%)$ & $96(99 \%)$ \\
\hline appellativ & $227(15,2 \%)$ & $75(77 \%)$ \\
\hline proprium & $189(12,7 \%)$ & $70(72 \%)$ \\
\hline sætning & $176(11,8 \%)$ & $69(71 \%)$ \\
\hline andet & $82(5,5 \%)$ & $51(53 \%)$ \\
\hline
\end{tabular}

Tabel 6. De forskellige typers hyppighed

Den ulige fordeling af de forskellige typer er ikke nogen stor overraskelse, opgavens indhold taget i betragtning. Da dette netop sigter til pronominers funktion som refererende enheder, er det naturligt og forventeligt, at der i næsten alle tekster forekommer pronominer som objektsproglige størrelser. De størrelser, der i analyseteksten fungerer som referenter (appellativer, proprier og sætninger), fordeler sig nogenlunde ligeligt.

Tabel 7 angiver, hvor stor en andel af den pågældende type der er markeret i det samlede korpus.

\begin{tabular}{|l|l|l|l|}
\hline & Antal forekomster & Antal markerede & Andel markerede \\
\hline pronomen & 820 & 714 & $87 \%$ \\
\hline appellativ & 227 & 120 & $53 \%$ \\
\hline proprium & 189 & 44 & $23 \%$ \\
\hline sætning & 176 & 171 & $97 \%$ \\
\hline andet & 82 & 44 & $54 \%$ \\
\hline ALLE & 1494 & 1085 & $73 \%$ \\
\hline
\end{tabular}

Tabel 7. Markering af de forskellige typer i korpus 
Tabel 8 viser, i hvor høj grad de enkelte tekster markerer de forskellige typer.

\begin{tabular}{|c|c|c|c|}
\hline \multicolumn{4}{|c|}{ Antal tekster, hvor } \\
\hline & $\begin{array}{l}\text { alle forekomster mar- } \\
\text { keres }\end{array}$ & $\begin{array}{l}\text { nogle forekomster } \\
\text { markeres }\end{array}$ & $\begin{array}{l}\text { ingen forekom- } \\
\text { ster markeres }\end{array}$ \\
\hline sætning (69) & $91 \%(64)$ & $6 \%(3)$ & $3 \%(2)$ \\
\hline pronomen (96) & $61 \%(59)$ & $38 \%(36)$ & $1 \%(1)$ \\
\hline appellativ (75) & $36 \%(27)$ & $33 \%(25)$ & $31 \%(23)$ \\
\hline proprium (70) & $17 \%(12)$ & $20 \%(14)$ & $63 \%(44)$ \\
\hline andet (51) & $45 \%(23)$ & $7 \%(3)$ & $48 \%(25)$ \\
\hline ALLE (97) & $12 \%(12)$ & $88 \%(85)$ & $0 \%(0)$ \\
\hline
\end{tabular}

Tabel 8. Markering af de forskellige typer i teksterne

Tabel 5 indikerede, at en stor gruppe studerende ganske vist kunne være tilbøjelige til at forsømme at markere alle objektsproglige størrelser, men dog generelt markerede en stor andel, hvilket kunne antyde, at manglende markeringer var udtryk for forglemmelser snarere end manglende kompetencer. Heroverfor viser tabel 8 , at problemet med markering er knyttet til bestemte ordklasser og derfor måske snarere har at gøre med, om den studerende overhovedet er tilbøjelig til at opfatte det pågældende fænomen som en objektsproglig størrelse.

En årsag til den høje grad af markering for sætningskategoriens vedkommende kan være, at der som nævnt er tale om det objektsproglige fænomen, der ligger tættest på eksemplet. Ved markering af eksempler udviser de studerende en langt højere grad af sikkerhed, end den vi ser ved de objektsproglige størrelser i løbende tekst som samlet hele. Dette kan skyldes, at en hel objektsproglig sætning, der indsættes i den løbende tekst, både indholdsmæssigt og syntaktisk stikker tydeligt ud. I de fem tilfælde, hvor objektsproglige sætninger ikke er markeret, ses (som kompensation) en sproglig signalering af deres status (jf. afsnit 3), fx i (18):

(18) Et eksempel kunne være: Kræmmeren sælger ikke længere bomuldslagner. Det gjorde han tidligere, men de solgte ikke særligt godt. Efter at han gået over til silke, går salget langt bedre. (tekst 99)

At pronominerne markeres forholdsvis hyppigt, kan ligeledes skyldes, at det i tekstsammenhængen ofte er tydeligt, at de ikke er en del af den studerendes egen tekst. Pronominer har grundlæggende en henvisende funktion; når de fungerer som en del af den studerendes egen tekst, vil referenten for pronomenet (typisk) være at finde i denne, hvilket ikke er tilfældet, når de har objektsproglig status. Herudover bøjes flere pronominer i kasus, og denne kasusbøjning beholder de, når de optræder som objektsproglige størrelser. I (19) nedenfor henviser det markerede den ikke til en referent i den studerendes egen tekst, hvilket også gælder de umarkerede det og de i (20). I (21) harmonerer den oblikke kasus ham ikke med funktionen som subjekt ( $i$ anden sammenhæng ville en sætning som ham står alt for langt vaek blive opfattet som grammatisk ukorrekt). 
(19) Man ser også eksemplet i linje 15 hvor det igen er en kataforisk reference, hvor "den" henviser til "debat". (tekst 154)

(20) I underrubrikken er der anvendt mange kohæsionsredskaber. Vi får her at vide, hvad de to ord står i stedet for. Det refererer til danskernes kommavaner (sæt. 3), de står i stedet for Dansk sprognævn (sæt. 2). (tekst 25)

(21) Artiklen afsluttes med disse ord: "..siger sprogforsker Jacob Thøgersen. Han er altså enig med ham i, at kommaet skaber problemer." (I. 45 - 47). Man må formode, at Thøgersen er uenig med Jørn Lund, der nævnes i linje 35. "Ham" står altså for langt væk fra, hvad det refererer til. (tekst 113)

Den objektsproglige status er dermed relativt nem at få øje på, hvilket kan være grund til, at den formelle markering typisk huskes.

Mens sætninger og pronominer som objektsproglige størrelser relativt tydeligt stikker ud fra den omgivende tekst, er indholdsordenes, mere specifikt substantivernes, status i en vis forstand mere flydende. Det gælder både appellativerne og - i særlig grad - proprierne. Eksempler på umarkerede objektsproglige appellativer ses i (22) (kommavaner, kommaet) og (23) (undersøgelserne):

(22) Der kan også argumenteres for, at proformeren bliver brugt som anaforisk reference til kommavaner, der nævnes i linje 3. Uden at set hvad, så går forfatteren ud fra, at læseren er underforstået med, at "det" er kommaet. (tekst 61)

(23) Pronomen de i linje 13 har intet referencepunkt i sætningen, hvor det er placeret. Det betydningsbærende referencepunkt er formentlig i de foregående sætninger, men det er uklart, hvorvidt de refererer til Dansk Sprognævn eller undersøgelserne. (tekst 41)

At appellativerne her skal forstås som objektsproglige størrelser - som "kommavaner i teksten" og ikke som "kommavaner i virkeligheden" - understreges af den studerende selv i den omgivende tekst, idet anaforiske referencer ikke er noget, der eksisterer i den ekstrasproglige virkelighed, men alene er et sprogligt fænomen (22), ligesom referencepunkter i (23) også må betragtes som et tekstfænomen. Ikke desto mindre bruges appellativer i language use jo netop til at betegne ekstrasproglige fænomener, hvilket kan besværliggøre klarlæggelsen af disses status. Herudover er appellativerne sjældent syntaktisk påfaldende, bl.a. fordi de modsat pronominerne ikke har en formmæssig kasusforskel.

At proprierne udgør et særligt stort problem, kan skyldes, at de i lighed med appellativerne betegner ekstrasproglige fænomener, og at de desuden typisk bruges med unik reference. Således bruges propriet Jørn Lund om én specifik person i den ekstrasproglige virkelighed, hvilket muligvis gør det sværere at erkende, at Jørn Lund i nærværende sammenhæng skal betragtes som et sprogligt fænomen. ${ }^{11}$ Selv i tilfælde, hvor den studerende gennem den omgivende tekst tydeligt signalerer, at propriet skal tilskrives objektsproglig status (kategoriseringen som "betydningsbærende morfem" i (24) eller linjehenvisningerne i (25)), ses i mange tilfælde fravær af markering:

\footnotetext{
${ }^{11}$ Empiriteksten indeholder proprier som navne på både personer (fx Jørn Lund) og institutioner (Dansk Sprogncevn). Om der er tale om den ene eller den anden type, er tilsyneladende ikke afgørende for, om markeringen huskes.
} 
(24) Proformen ham skal i den her sætning føre tilbage til det betydningsbærende morfem Jørgen Lund. (tekst 2)

(25) I linje 23 er det utydeligt hvem det er ordet ham er i kohæsion med. Det kan både være Jørn Lund i linje 22 og Henrik Galberg Jacobsen i linje 23.

Konventionen for objektsprogsmarkering tager ikke hensyn til en typemæssig opdeling af de objektsproglige størrelser, men nærværende delanalyse peger i retning af, at netop typen er afgørende for de studerendes forståelse af, hvad der er markeringskrævende objektsprog.

\subsubsection{Markeringens form}

De udtryksressourcer, der anvendes til markering af objektsproglige størrelser i løbende tekst, fremgår af tabel 9:

\begin{tabular}{|l|l|l|}
\hline Markeringsform & Antal forekomster & Fordelt på antal tekster \\
\hline dobbelt citationstegn & $472(43,2 \%)$ & 67 \\
\hline kursiv & $367(33,6 \%)$ & 47 \\
\hline enkelt citationstegn & $148(13,6 \%)$ & 15 \\
\hline kursiv + dobbelt citationstegn & $56(5,1 \%)$ & 17 \\
\hline kursiv + understregning & $28(2,6)$ & 1 \\
\hline fed & $16(1,5 \%)$ & 1 \\
\hline majuskler & $3(0,3 \%)$ & 1 \\
\hline kursiv + fed & $3(0,3 \%)$ & 1 \\
\hline i alt & 1093 & \\
\hline
\end{tabular}

Tabel 9. Markeringsformer for objektsproglige størrelser i løbende tekst

Som ved eksemplerne ser vi også her en række udtryksressourcer i form af tegnsætning eller typografi, der tjener det formål at afgrænse objektsproget visuelt i forhold til den omgivende tekst. Kun ved ca. en tredjedel af forekomsterne bruges kursiv som eneste markering, så vi må konstatere, at de studerende enten ikke kender til kursivkonventionen (jf. afsnit 3) eller i hvert fald ikke følger denne, samt at et fåtal trækker på den information, de vil kunne udlede af teoritekstens markeringsstrategi (jf. afsnit 4). Fælles for de anførte ressourcer er dog, at de alle formår at skabe en modsætning mellem de to tekstlag.

Hvad angår konsekvens i brug af markeringsform, bruger 47 tekster samme markering, mens 48 veksler mellem forskellige former (to tekster indeholder kun én forekomst). 
Tabel 10 viser de former, der anvendes i de 47 konsekvente tekster:

\begin{tabular}{|l|l|}
\hline Markeringsform & Antal \\
\hline kursiv & 16 \\
\hline dobbelt citationstegn & 25 \\
\hline enkelt citationstegn & 4 \\
\hline kursiv + understregning & 1 \\
\hline kursiv + dobbelte citationstegn & 1 \\
\hline
\end{tabular}

Tabel 10. Markeringsform i konsekvente tekster

De resterende 48 tekster kan vi vælge umiddelbart at afskrive som inkonsekvente i deres brug af markeringsform. Vi kan imidlertid i 23 af disse iagttage en brug, der måske ikke lever op til konventionen, men som ikke desto mindre er systematisk og logisk på sine egne præmisser, idet inkonsekvensen i disse opgaver skyldes, at der vælges en markeringsform til sætninger og en anden til de øvrige typer af objektsproglige størrelser. Dette fremgår af tabel 11:

\begin{tabular}{|l|l|l|}
\hline Markering af sætning & Markering af øvrige & Antal \\
\hline dobbelt citationstegn & kursiv & 12 \\
\hline dobbelt citationstegn & enkelt citationstegn & 4 \\
\hline kursiv & dobbelt citationstegn & 2 \\
\hline $\begin{array}{l}\text { kursiv + dobbelt citations- } \\
\text { tegn }\end{array}$ & dobbelt citationstegn & 3 \\
\hline $\begin{array}{l}\text { kursiv + dobbelt citations- } \\
\text { tegn }\end{array}$ & kursiv & 1 \\
\hline dobbelt citationstegn & kursiv + fed & 1 \\
\hline & & 23 \\
\hline
\end{tabular}

Tabel 11. Markeringsformer i "inkonsekvente" tekster

Vi kan antage, at forskellen i markering angiver, at de pågældende studerende har forskellig forståelse af sætninger og ikke-sætninger og disses status som objektsproglige størrelser. Dette kan hænge sammen med den tidligere adresserede skelnen mellem eksempler og objektsproglige størrelser i løbende tekst, idet eksempler typisk vil have sætningsform.

Resultatet af vores analyse peger i retning af, at de studerende i høj grad har en forståelse af behovet for at markere objektsprog og dermed tydeliggøre tekstens forskellige lag for læseren. Omvendt vidner teksterne ikke om et bredt kendskab til konventionerne for markeringsform, idet mange studerende anvender andre former end de gængse. Mens formforståelsen endnu ikke er fast etableret, synes indholdsforståelsen og det dermed forbundne udtryksbe- 
hov i høj grad at være til stede. At nogle studerende skelner mellem forskellige typer af objektsprog i deres markeringsstrategi, tyder dog på, at deres fortolkning af indholdet ikke er i fuld overensstemmelse med fagfællesskabets.

\section{Diskussion}

Vi har i vores undersøgelse haft fokus på et aspekt af intertekstualitet, der er underlagt en række fagspecifikke konventioner. Ud fra et snævert korrekthedsperspektiv kunne en udlægning af resultaterne være, at kun fire tekster/studerende lever op til de konventioner for markering af objektsprog, som er præsenteret i afsnit 3, ved konsekvent at markere eksempler og objektsprog og gøre dette i overensstemmelse med konventionen - en enkelt af teksterne gør endda kun dette ved slet ikke at indeholde eksempler og objektsproglige størrelser. Når vi har medtaget så mange mellemregninger og overvejelser, som tilfældet er, er det netop, fordi vores ærinde som indledningsvis nævnt er at anskue de studerende, der har deltaget i undersøgelsen, som potentielle medlemmer af et fagligt fællesskab og deres tekster som et vidnesbyrd om, i hvor høj grad de har tilegnet sig de tekstskrivningskompetencer, der er knyttet til dette fællesskab.

Fra et receptionsperspektiv er der ikke noget i de studerendes tekster, der antyder, at de har problemer med at afkode teoritekstens brug af kursiv og layout som markering af objektsprog. I et produktionsperspektiv viser resultaterne imidlertid, at denne forståelse i de fleste tilfælde ikke overføres til de studerendes eget skriftlige produkt. Markering af objektsproglige størrelser ser altså ud til at udgøre et område for fagspecifik tavs viden, og vores undersøgelse indikerer således, at der er behov for en skrivepædagogisk indsats, der sikrer, at den studerende opnår en grundlæggende forståelse af empiritekstens funktion i den akademiske opgave: at den er selve objektet for den studerendes videnskabelige undersøgelse, og at den videnskabelige undersøgelses troværdighed afhænger af transparens i udvælgelsen og inddragelsen af empiriteksterne. I forlængelse heraf er det vigtigt at lægge vægt på, at transparensen hænger intimt sammen med måden, hvorpå empiriteksten markeres. Vi vil her pege på nogle mulige skrivepædagogiske indsatsområder, der kan bidrage til at fremme den studerendes forståelse af disse fundamentale træk ved den akademiske opgavegenre. Først og fremmest vil bevidstgørelse om specifikke valg og fravalg (rhetorical consciousness raising, jf. Hyland, 2013) kunne tilføre de studerende forståelse for formalias betydning for de akademiske opgavers kvalitet og for, at ethvert valg eller fravalg har betydning. Ud fra et dialogistisk perspektiv kan den akademiske opgave netop forstås som en genre med særlige regler og normer for at håndtere intertekstualitet (Chatterjee-Padmanabhan, 2014). En overordnet introduktion til intertekstualitetsbegrebet og konventionerne for omgang med dette inden for andre teksttyper, fx medietekster og litteratur, kan i denne sammenhæng medvirke til at løfte problemstillingen ud over formalitetsperspektivet og herigennem bibringe de studerende en øget opmærksomhed over for konventionerne for markering af intertekstualitet og dennes rolle som konstituerende element i den akademiske opgavegenre. I et større perspektiv vil denne erkendelse føre til en dybere forståelse af den videnskabelige genre som bestående af en række registre, der tilbyder særlige tænke- og handlemuligheder, som giver adgang til at kommunikere budskaber af særlig kompleks art (Bazerman, 2004). Ydermere udgør objektsprogsmarkering et eksempel på nødvendigheden af multimodal tekstskrivningskompetence, da der kræves en bevidsthed om ikke-sproglige ressourcers bidrag til tekstens betydning. Endelig peger resultaterne i afsnit 5.2.1 på, at et fokus på bestemte ordklassers status som objektsprog er nødvendigt. 
Vores undersøgelse omfattede 100 studenteropgaver fra en årgang på dansk- og journalistikstudiet. Vi kan derfor ikke vide, hvordan studerende på andre studier eller årgange ville håndtere objektsproglige størrelser og eksempler i empiritekster. Det ville derfor styrke reliabiliteten af vores undersøgelse, hvis materialet udvides ved en eller flere gentagelser. Vi må ligeledes tage det forbehold, at opgaven er skrevet under tidspres, hvilket kan have påvirket udfaldene, ligesom den uvante situation kombineret med det forhold, at opgaven ikke kunne dumpes, kan have haft indflydelse på de studerendes valg og fravalg. Endelig har vi i undersøgelsen alene haft fokus på, hvad de studerende gør, og ikke på, hvad de siger eller tror, at de gør. Dette aspekt ville kunne udforskes yderligere gennem fx interviews eller spørgeskemaer.

\section{Konklusion}

I vores undersøgelse har vi fundet, at de nyindskrevne studerende udviser nogenlunde sikkerhed ved markering af eksempler, men er mere usikre, når det gælder objektsproglige størrelser i løbende tekst. Undersøgelsen viser også, at der er forskel på, i hvor høj grad den studerende markerer de forskellige typer af objektsproglige størrelser, hvilket kan skyldes, at funktionsord og hele sætninger er lettere at få øje på end indholdsord. Vi iagttager endvidere, at de studerende ikke er konsekvente i valg af markering. De følger ikke konventionen, og de udleder den ikke af teoriteksten, selv om de kunne hente hjælp ved at iagttage, hvordan markeringerne foretages i denne.

Vores undersøgelse har vist et eksempel på hidden literacy inden for et særligt fagområde, der ikke eksplicit behandles i håndbogslitteratur om opgaveskrivning. Det er dog vores antagelse, at der inden for alle fagtraditioner kan findes sådanne eksempler på hidden literacies, som det er vigtigt at afdække. Opmærksomhed over for tilstedeværelsen af sådanne skjulte konventioner giver efter vores mening mulighed for, at man i undervisningen i akademisk skrivning kan belyse de retoriske funktioner, der er knyttet til de umiddelbart mere formelle træk i den akademiske tekst, og på den måde bidrage til kvalificeret forståelse af nogle af den videnskabelige genres konstituerende elementer.

\section{Bibliografi}

Bakhtin, M. M. (1981). The Dialogic Imagination: Four Essays. Austin: The University of Texas Press.

Barton, D., Hamilton, M. \& Ivanic, R. (Eds.) (2000). Situated Literacies: Reading and Writing in Context. London: Routledge.

Bazerman, C. (2004). Speech acts, genres, and activity systems: How texts organize activity and people. I: C. Bazerman \& P. Prior (Eds.), What writing does and how it does it: An introduction to analyzing texts and textual practices (309-339). Mawah, NJ: Erlbaum.

Blom, J. N., Rathje, M., Jakobsen, B. L. F., Holsting, A., Reinecke Hansen, K., Svendsen, J. T., Lindø, A. V. (2017). Linguistic Deviations in the Written Academic Register of Danish University Students. Oslo Studies in Language, 9(3), 169-190.

Burgess, A. (2004). New discourses, new identities: A study of writing and learning in adult literacy education. Literacy and Numeracy Studies, 13(2), 41-60. 
Bußmann, H. (1990). Lexikon der Sprachwissenschaft (2. udg.). Stuttgart: Kröner.

Chatterjee-Padmanabhan, M. (2014). Bakhtin's theory of heteroglossia/intertextuality in teaching academic writing in higher education. Journal of Academic Language \& Learning, 8(3), A101-A112.

Esser, J. (2006). Presentation in Language: Rethinking Speech and Writing. Tübingen. Günter Narr Verlag.

Fairclough, N. (1992). Discourse and Social Change. Cambridge: Polity Press.

Hagiwara, R. (2005). Notes on linguistic style. Lokaliseret 23. februar 2019 på: http://home.cc.umanitoba.ca/ robh/files/lxstyle.pdf

Haspelmath, M. (2014). The Generic Style Rules for Linguistics. Lokaliseret 23. februar 2019 på: https://www.eva.mpg.de/lingua/pdf/GenericStyleRules.pdf

Hjelmslev, L. (1963/1973). Sproget: En introduktion (2. udg.). København: Munksgaard. Rosinante.

Holm, L. (2007). Fra ord til saetning til tekst. Tekstlingvistik i danskfaget. Frederiksberg: Dansklærerforeningen.

Holsting, A., Svendsen, J. T., Lindø, A. V., Iversen, D. L., Blom, J. N., Rathje, M. \& le Fevre Jakobsen, B. (2017). "Det første begreb i teksten er...": En undersøgelse af henvisningsformer i nyindskrevne universitetsstuderendes akademiske opgaver. Rask, 46 (Autumn), 21-62.

Hyland, K. (2013). Teaching language for academic purposes. I: C. Chappele (Eds.) The Encyclopaedia of Applied Linguistics. Oxford: Wiley-Blackwell.

Ivanic, R. (1998). Writing and Identity: The discoursal construction of identity in academic writing. Amsterdam: John Benjamins Publishing Company.

Kress, G. (2003). Literacy in the new media age. London \& New York: Routledge.

Kress, G. \& van Leeuwen, T. (2001). Multimodal discourse: The modes and media of contemporary communication. London: Arnold.

Lea, M. R. (2004). Academic literacies: A pedagogy for course design. Studies in Higher Education 29(6), 739-756.

Lea, M. \& Street, B. (1998). Student writing in higher education: An academic literacies approach. Studies in Higher Education. Studies in Higher Education 23, 157-172.

Lea, M.R. \& Street, B.V. (2006). The "Academic Literacies" Model: Theory and Applications. Theory Into Practice, 45(4), 368-377

Lehmann, C. (2013). Objektsprache und Metasprache. Lokaliseret 23. februar 2019 på: https://www.christianlehmann.eu/ling/epistemology/techniques/redaction/index.htm l?https://www.christianlehmann.eu/ling/epistemology/techniques/redaction/Objekt\& Metasprache Typographie.html

Machin, D. (2007). Introduction to multimodal analysis. London: Hodder Education.

Osmond, A. (2016). Academic writing and grammar for students (2. udg.). London: Sage. 
Pecorari, D. \& Petrić, B. (2014). Plagiarism in second-language writing. Language Teaching 47(3), 269-302.

Rienecker, L. \& Jørgensen, P. S. (2005). Den gode opgave: Håndbog i opgaveskrivning på videregående uddannelser (3. udg.). Frederiksberg: Samfundslitteratur.

Rienecker, L. \& Jørgensen, P. S. (2017). Den gode opgave: Håndbog i opgaveskrivning på videregående uddannelser (5. udg.). Frederiksberg: Samfundslitteratur.

Robinson-Pant, A. \& Street, B. (2012). Students' and tutors' understanding of 'new' academic literacy practices. I: M. Castelló \& C. Donahue (Eds.), University writing: Selves and texts in academic societies (71-92). London: Emerald Group Publishing Limited.

Scott, M., \& Turner, J. (2009). Reconceptualizing student writing. I: T. Lillis \& S. Parkin (Eds.), Why writing matters: Issues of access and identity and writing research and pedagogy (129-150). Philadelphia: John Benjamins Publishing Company.

Snow, C. E. \& Uccelli, P. (2009). The challenge of academic language. I: D. R. Olson \& N. Torrance (Eds.), The Cambridge Handbook of Literacy (s. 112-133). Cambridge: Cambridge University Press.

Street, B. (2010). 'Academic Literacies approaches to Genre'. Revista Brasileira de Linguística Aplicada, 10(2), 347-361.

Swales, J. (1990). Genre Analysis: English in Academic and Research Settings. Cambridge: Cambridge University Press.

Swales, J. M. \& C. B. Feak (2012). Academic Writing for Graduate Students (3. udg.). Ann Arbor: The University of Michigan Press.

Toft, T. (2016): Bachelorprojektet: Sådan gør du! Svendborg: Pretty Page.

Verheijen, L. (2015). The language of quoting in academic writing. Dutch Journal of Applied Linguistics 4(1), 101-121.

Wegener, C. (2016). Skriv med gloede: En guide til akademisk skrivning. Frederiksberg: Samfundslitteratur.

Wilson, S. (2011). A Computational Theory of the Use-Mention Distinction in Natural Language. Lokaliseret 23. februar 2019 på: http://www.cs.umd.edu/active/publications/papers/dissertations/swilson dissertation web.pdf 